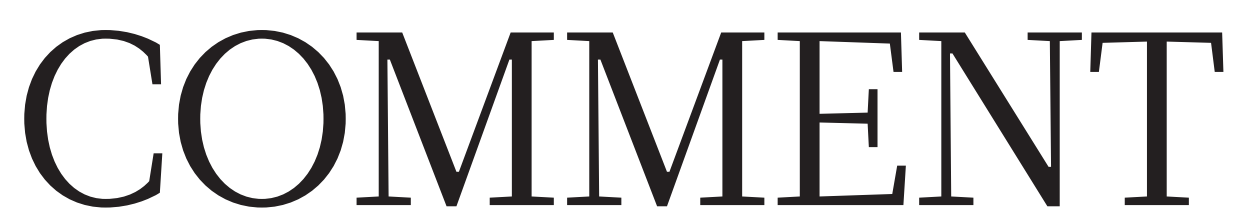

NEUROSCIENCE Split-brainstudy pioneer writes juicy biography $\mathbf{p . 2 9 8}$

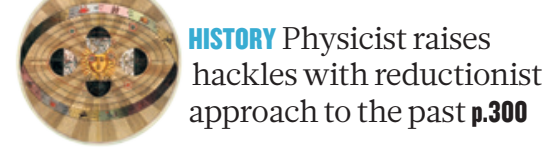

THEATRE Royal Shakespeare

Company tackles

Oppenheimer tragedy $\mathbf{p . 3 0 1}$
OBITUARY Vernon B.

Mountcastle, cortical

visionary, remembered p.304

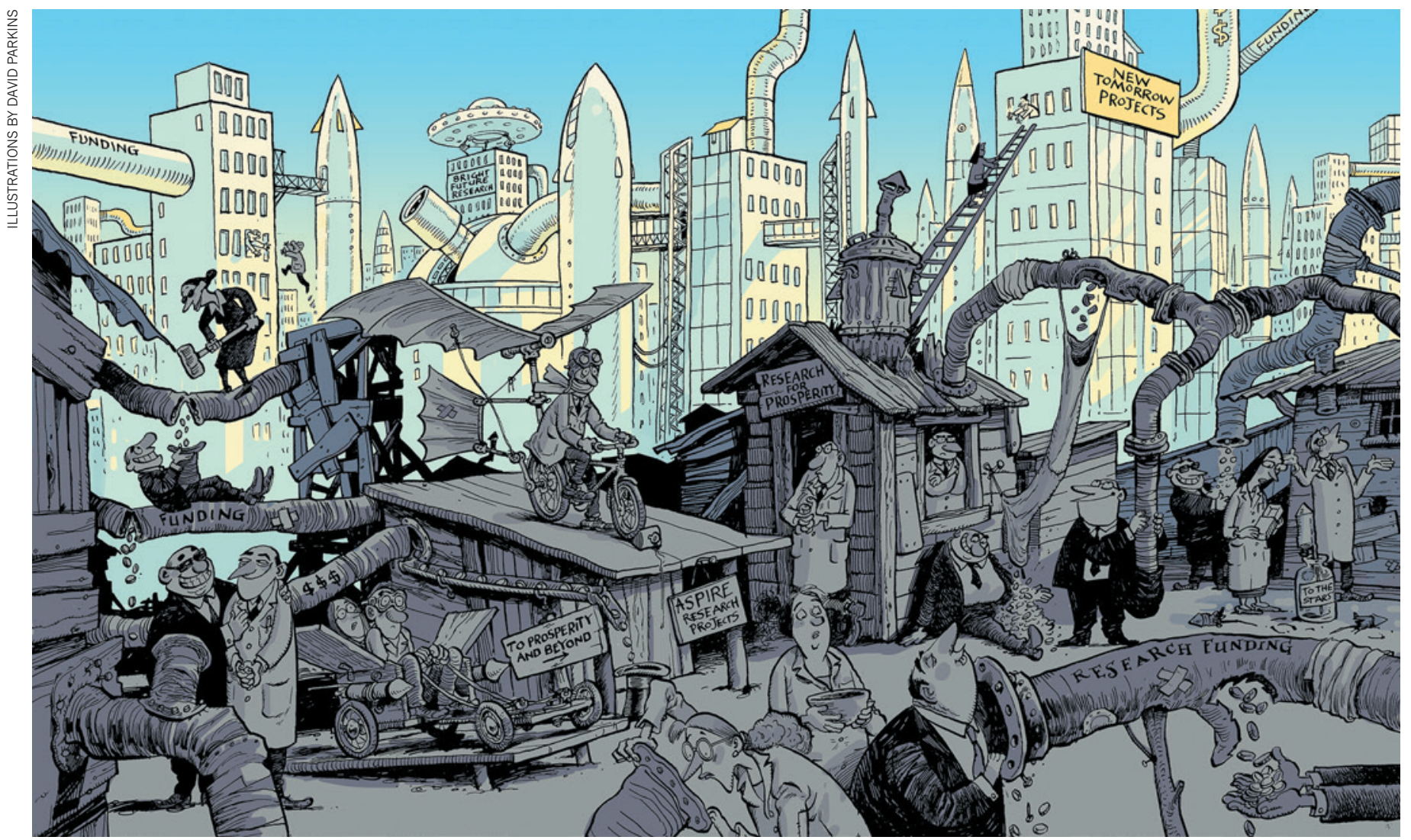

\title{
Good governance powers innovation
}

Corruption is a barrier to innovation, warns Alina Mungiu-Pippidi. Greater scrutiny of public spending is needed if science and technology are to fulfil their potential.

$\mathrm{F}$

Tormer European Commission president José Manuel Barroso, in his 2013 state of Europe address, pointed to "new science studies, from new technologies" as a key to sustaining economic growth. Similarly, US President Barack Obama stressed the importance of innovation in economic recovery in his 2014 state of the union address: "Today in America ... an entrepreneur flipped on the lights in her tech start-up, and did her part to add to the more than 8 million new jobs our businesses have created over the past four years." And pledges and encouragements for innovators in the developing world have come from agencies including the World Bank and World Economic Forum.

Innovation is key to prosperity. But corruption is inimical to innovation. If firms and individuals are to be creative, and if their societies are to make the best use of that, competition and hard work must be more strongly valued than reliance on connections. My analyses show that governance that results in such societies is rarer than people think.

\section{TOP THIRD}

If you know how corrupt a country is, you can predict fairly accurately how much innovation you will see there (see $>$ 
' 'Virtuous circles'). In the European Union (EU), the private sector's capacity for innovation strongly correlates with control of corruption (a correlation of 0.84 ), with quality of national scientific research institutions (0.85), and with gross domestic expenditure on research and development (0.9). Corruption in this analysis is defined as the abuse of public authority for private interest, resulting in a biased allocation of public resources. Control of corruption, assessed by the World Bank, is defined as the capacity of a society to restrict authorities from distributing public goods and resources in their own interests.

A country ranked below the upper third on the scale for control of corruption will not have much innovation. Of the world's 114 democracies, only 35 are above that line, along with only 3 out of 78 countries that do not hold free elections. Romania, Bulgaria, Greece and Italy have the poorest corruption control in the EU, whereas the Nordic countries have the best, followed by the Netherlands, the United Kingdom and Germany. Outside Europe, New Zealand, Canada and Australia lead, in front of the United States, which remains the world's most populous country where corruption is reasonably well controlled.

\section{FAVOURITISM RULES}

Research ${ }^{1}$ reveals that favouritism is much more widespread than previously thought. A merit-based society takes several generations to develop, and has been achieved in only about 25 countries. These are the same nations that are on top of corruption control: those in a Nordic cluster, an Anglo-Saxon cluster, a German-speaking cluster and a few others ${ }^{2}$. Only these societies have managed to create a social system in which everyone is treated similarly, so abuse of authority does not distort the allocation of public money.

Outside these 25 nations, citizens have little trust in their institutions. Nearly two-thirds of 114,000 respondents in 107 countries surveyed $^{3}$ in 2013 believed that personal connections are the key factor to getting things done in the public sector - from the

\section{VIRTUOUS CIRCLES}

Research spending (A) and innovation (B) are low in European nations judged to be corrupt by the Worldwide Governance Indicators (WGI), causing talented people to flee (C). Meritocratic, democratic countries invest in science and education, which drives economic progress.
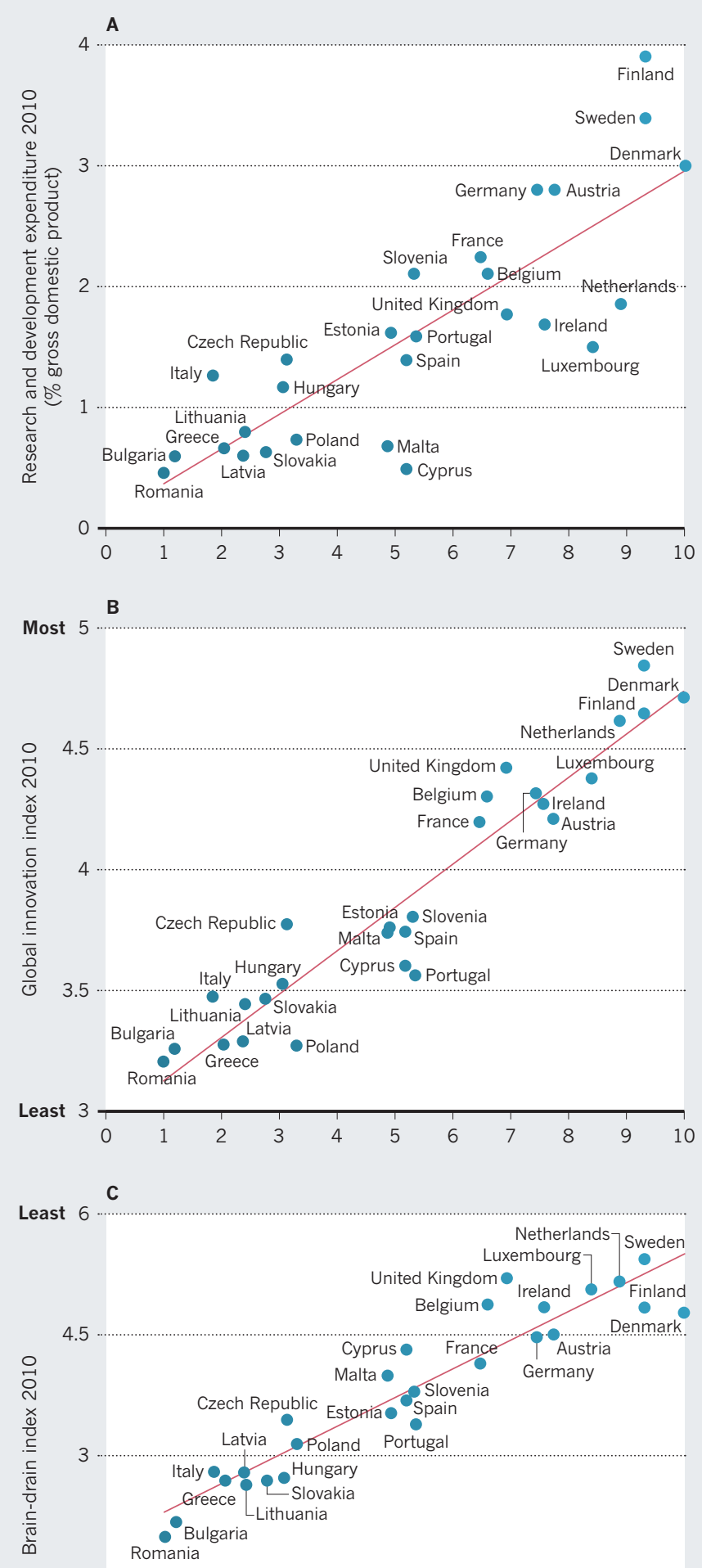

1.5

Most 0

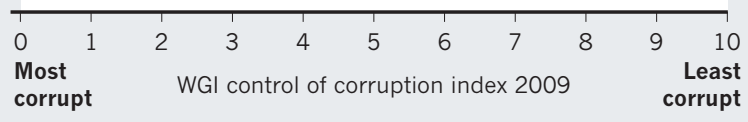

allocation of jobs in universities to the distribution of statesponsored research funds. In the EU, a survey of roughly 85,000 respondents ${ }^{4}$ found that many Europeans complain of favouritism in both public and private sectors. Only in northern Europe (including France) did the majority of people believe that merit prevails. In Mediterranean countries, the two groups were nearly even; in Eastern European countries that have recently become EU members, favouritism was perceived as the dominant exchange.

Such perceptions are grounded in experiences with all aspects of school, professional and public life. Societies in which people feel this cynicism become locked in a vicious cycle: talent flees to meritocratic countries or is unproductive, further eroding their own nations' development ${ }^{5}$. Although better-educated people declare themselves to be less tolerant of corruption, they offer no fewer bribes than educated ones (see go.nature.com/lmatfw).

\section{WHO WOOS WHOM}

Why does innovation capacity mirror the quality of governance? Not because talent is unevenly distributed across countries and not entirely because of poverty - which, of course, plays a part because it means poorer infrastructure for innovation and technology. Romania and Bulgaria are the poorest countries in Europe, but Italy and Greece are by no means underdeveloped.

Simply, where advancement based on merit is the rule and favouritism the exception, governments and markets alike promote value, and prosperity results. In places where such a system fails to take hold, social allocation is directed preferentially rather than ethically. In these contexts, science and research are marginalized because those in power fear that talent threatens their main aim - controlling access to public and private resources.

Governments that buy political support do not invest much in education and research - the returns are seen as too general. A sports stadium or a new airport woos the companies chosen 


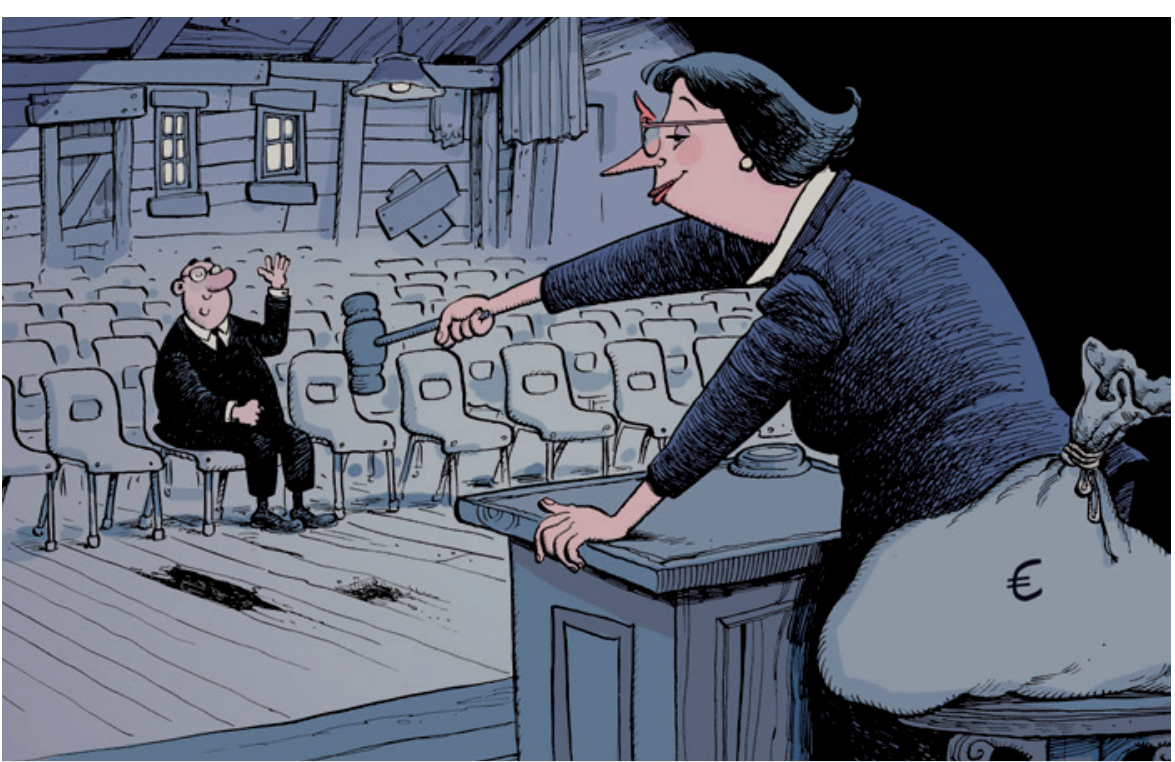

CORRUPTION INDICATORS

\section{Single bidding}

During the process of bidding to acquire public funds - to win a contract for, say, building a hospital or an airport - 'single bidding' is when just one candidate participates and wins. In most countries, procurement legislation requires that alternative offers are sought, especially for bigger projects, so that the process is competitive and offers the best value for taxpayer money.

In corrupt countries, single bidding is common, because everyone knows that particular companies will win and others do not want to lose time or fees taking part in a sham contest. In exceptional cases, single bidding is unavoidable NASA had no competitor in launching publicly funded space shuttles - but in most cases it is an indicator of government favouritism.

My examination of data on contract procurement from the European Union's
Tenders Electronic Daily database (see go.nature.com/pff2nu), shows that there is much room for improvement. In Sweden, Denmark and the Netherlands, a maximum of $6 \%$ of contracts have single bidders; Croatia and Poland are at about $40 \%$.

The research, training and education sectors raise similar concerns. In the United Kingdom, less than 3\% of contracts have only one bidder in research or education projects; Poland is at $73 \%$ and $59 \%$, respectively. Post-communist countries are doing particularly badly on this front.

Such figures are likely to be just the tip of the iceberg. How many apparently competitive tenders or postings for public-sector jobs are in fact settled behind closed doors? Countries with limited public funds must increase competitiveness for contracts before they increase the funds themselves. A. M.-P.

were made to EU member states not to promote austerity to areas credited in the Horizon 2020 research and innovation funding strategy with economic recovery potential. This makes it all the more concerning that Jean-Claude Juncker, the European Commission's current president, plans to divert some of the money earmarked for research to economic stimulus. Research is what fuels development; 'growth' projects are mostly associated with corruption ${ }^{6}$.

\section{WATCHDOGS NEEDED}

The amount of public funding for research and development is frequently discussed, but the integrity of its disbursement is neglected. The EU needs instruments to oversee and intervene in national allocation rules.

To expose problematic practices, indicators - such as competitive distribution of research and education funds - need to be monitored closely, by pan-European watchdogs (both public and non-profit organizations) and by the European Commission. The results could be used to place conditions on a country's participation in various European funding schemes for research, education and innovation. The European Commission has developed a detailed monitoring and advice system for member states' economic performance, known as the European Semester. This could be expanded to include governance targets.

Much more activism is needed at the domestic level, too, from civil society, universities and local research communities. Technology helps enormously with fiscal transparency and more national civil-society watchdogs (such as those listed by the European Research Centre for Anti-Corruption and State-Building, see www.againstcorruption.eu) are needed to report on the integrity of public spending, especially on research and education. Large infrastructure projects are currently much better scrutinized than training or research grants.

For science and technology to fulfil their potential for growth, they must be empowered by a combination of funding and good governance. The impetus cannot come only from above. Reluctant national governments must be both led by the European Commission - a chief promoter of growth and innovation in Europe - and held to account by demanding domestic civil societies and science communities.

Alina Mungiu-Pippidi is professor of democracy studies at the Hertie School of Governance in Berlin, Germany. e-mailpippidi@hertie-school.org

1. Mungiu-Pippidi, A. in The Anticorruption Report, Vol. 2: The Anticorruption Frontline 90-124 (ed. Mungiu-Pippidi, A.) (Barbara Budrich, 2014); available at http://go.nature.com/toyusw.

2. North, D. C., Wallis, J. J., \& Weingast, B. R. Violence and Social Orders: A Conceptual Framework for Interpreting Recorded Human History (Cambridge Univ. Press, 2013).

3. Transparency International Global Corruption Barometer 2013 (Transparency International, 2013); http://go.nature.com/wnwjjc.

4. Charron, N. From Åland To Ankara: European Quality Of Government Index (The Quality of Government Institute, Gothenburg Univ. 2013); available at http://doi.org/z78.

5. Ariu, A. \& Squicciarini, M. P. EMBO reports 14 502-504 (2013).

6. Mungiu-Pippidi, A. \& Kukutschka, R. M. B. in The Anticorruption Report, Vol. 1: Controlling Corruption in Europe 14 (ed. Mungiu-Pippidi, A.) (Barbara Budrich, 2013); available at http:// go.nature.com/goo4in. 